\title{
Occurrence of autoantibodies to human leucocyte elastase in Wegener's granulomatosis and other inflammatory disorders
}

Jan Willem Cohen Tervaert, Leontine Mulder, Coen Stegeman, Job Elema, Minke Huitema, Hauw The, Cees Kallenberg

\begin{abstract}
Antineutrophil cytoplasmic antibodies (ANCAs) constitute a new class of autoantibodies that seem to recognise myeloid lysosomal enzymes. The occurrence of ANCAs with specificity for human leucocyte elastase (HLE) was assessed in serum samples that were routinely submitted for ANCA determination. During a study period of more than six years anti-HLE was found in only six out of 1102 serum samples that produced a perinuclear or an atypical cytoplasmic staining pattern on ethanol fixed granulocytes. These six serum samples were from four patients with a clinical diagnosis of Wegener's granulomatosis but without a definite histological diagnosis, one patient with systemic vasculitis, and one patient with Cogan's syndrome. To further evaluate the prevalence of anti-HLE we tested 315 serum samples from patients with different forms of vasculitis and related disorders. Anti-HLE was detected in two patients only. Thus autoantibodies to HLE are rarely found in serum samples from patients with vasculitic or related disorders.
\end{abstract}

(Ann Rheum Dis 1993; 52: 115-120)

The demonstration of autoantibodies to neutrophil cytoplasmic antigens (ANCAs) in systemic vasculitides such as Wegener's granulomatosis, classic polyarteritis nodosa, and the ChurgStrauss syndrome, and in idiopathic crescentic glomerulonephritis has placed these disorders within the class of autoimmune diseases. ${ }^{1}$ Two major types of ANCAs have been recognised. ${ }^{2}$ The first type is called c-ANCA ('classic' or 'cytoplasmic' ANCA) and is strongly associated with Wegener's granulomatosis. ${ }^{3-5}$ These antibodies produce a characteristic granular cytoplasmic staining pattern on ethanol fixed granulocytes when detected by a standard indirect immunofluorescence technique. ${ }^{6}$ Recently, it has been shown that the antigen recognised by c-ANCA is identical to proteinase 3, a 29 kilodalton glycoprotein from azurophilic granules with serine protease, antibiotic, and myeloblastic activity. ${ }^{7-11}$ The second type of ANCA is called p-ANCA ('perinuclear' ANCA). A substantial number of p-ANCA positive serum samples were shown to contain autoantibodies to myeloperoxidase. ${ }^{12} 13$ These antibodies produce a perinuclear pattern on ethanol fixed cytocentrifuged granulocytes, but a cytoplasmic staining pattern when granulocytes are treated with cross linking fixatives, ${ }^{12}$ or when freshly prepared thin blood smears are used as a substrate. ${ }^{14}$ Myeloperoxidase antibodies are found in patients with idiopathic crescentic glomerulonephritis (that is, without systemic vasculitis), crescentic glomerulonephritis associated with vasculitis, or alveolar haemorrhage, or both, hydralazine induced glomerulonephritis, and in patients with ChurgStrauss syndrome or classic polyarteritis nodosa. ${ }^{12} 13$ 15-17

Recently, it became apparent that a substantial number of $\mathrm{p}$-ANCA positive serum samples do not react with myeloperoxidase. ${ }^{16} 1819$ Serum samples positive for p-ANCA but negative for myeloperoxidase antibodies may be directed to other myeloid enzymes, such as human leucocyte elastase (HLE) $)^{713}$ or lactoferrin. ${ }^{19}{ }^{20}$ Antibodies to HLE have been described in some patients with vasculitis, ${ }^{1721}$ in patients with hydralazine induced glomerulonephritis, ${ }^{15}$ and occasionally in patients with systemic lupus erythematosus. ${ }^{15} 22$ Because the clinical significance, that is, the prevalence and possible clinical associations of autoantibodies specific for HLE is not well delineated, we further investigated the clinical associations of these antibodies by analysing clinical data of all consecutive patients whose serum samples were routinely submitted for determination of ANCAs and were positive for HLE antibodies. We also tested for the prevalence of this autoantibody in a large group of clinically well characterised patients.

\section{Patients and methods}

SERUM SAMPLES

About 9000 serum samples were sent to our laboratory between June 1984 and April 1991 to be tested for ANCAs. These samples were, in general, derived from patients with a suspected diagnosis of vasculitis or glomerulonephritis from different Dutch hospitals. A total of 913 produced a perinuclear or nuclear staining pattern and 189 produced an atypical cytoplasmic staining pattern on ethanol fixed granulocytes. These 1102 serum samples were selected for testing for HLE antibodies by enzyme linked immunosorbent assay (ELISA). Also, 50 consecutive serum samples that produced a cytoplasmic staining pattern (c-ANCA) on ethanol fixed granulocytes and were simultaneously positive for anti-proteinase 3 by ELISA, and 218 serum samples from normal controls were tested for the presence of HLE antibodies by ELISA.

COLLECTION OF CLINICAL DATA

Clinical details of the patients with HLE 
antibodies were collected. Charts were reviewed according to a protocol with emphasis on histological findings and signs and symptoms associated with vasculitic syndromes. ${ }^{16}$

\section{PATIENTS}

To further define the significance of HLE antibodies in relation to proteinase 3 antibodies and myeloperoxidase antibodies we tested serum samples from all consecutive patients with classic polyarteritis nodosa $(n=9)$, polyangiitis overlap syndrome $(n=12)$. ChurgStrauss syndrome $(n=10)$, temporal arteritis $(n=12)$, and Takayasu's arteritis $(n=4)$ who were seen at the department of internal medicine between June 1984 and April 1991. Diagnoses were based on clinical, histological, and/or angiographic criteria. ${ }^{1723}$ Serum samples were also tested from consecutive patients with chronic midline destructive disease $(n=14)$ diagnosed by the presence of a progressive and locally destructive disease involving the nose, paranasal sinuses, or palate. ${ }^{24}$ Nasal biopsies showed granulomatous inflammation with or without vasculitis-compatible with Wegener's granulomatosis-in 13 of 14 patients. None of these patients, however, had systemic disease with kidney involvement as seen in generalised Wegener's granulomatosis.

Serum samples were also tested from all consecutive patients with pauci-immune crescentic glomerulonephritis $(n=45),{ }^{13}$ subclassified as Wegener's granulomatosis when granulomatous inflammation of the respiratory tract or respiratory tract symptoms compatible with Wegener's granulomatosis were present, or as idiopathic glomerulonephritis when systemic or respiratory tract manifestations were absent.

Finally, serum samples were tested from patients with cutaneous vasculitis $(n=14)$, systemic lupus erythematosus with or without central nervous system involvement ${ }^{25}(n=38)$, rheumatoid arthritis $(\mathrm{n}=38)$, sarcoidosis $(n=16)$, mycobacterial infection $(n=14)$, inflammatory bowel disease $(n=59)$, autoimmune liver disease $(n=30$, comprising primary sclerosing cholangitis $(n=8)$, primary biliary cirrhosis $(n=15)$, and autoimmune chronic active hepatitis $(\mathbf{n}=7)$.

Serum samples were obtained when the disease in question was in active phase.

\section{DETECTION OF ANTIBODIES BY INDIRECT} IMMUNOFLUORESCENCE

Detection of ANCAs was performed as previously described ${ }^{35}$ with minor modifications. ${ }^{26}$ Briefly, granulocytes from a healthy donor were obtained by Isopaque-Ficoll and dextran sedimentation of heparinised blood. After washing the cells, $25 \mu \mathrm{l}$ of a suspension of $1 \times 10^{6}$ granulocytes $/ \mathrm{ml}$ were put into each well of 12 well Cooke slides at $37^{\circ} \mathrm{C}$ for 30 minutes. After attachment to the wells, cells were ethanol fixed for 10 minutes at $4^{\circ} \mathrm{C}$. Test or control serum samples were overlaid in a dilution of 1:16 on the slides and incubated for one hour. After washing thrice with phosphate buffered saline (PBS) for five minutes, bound antibody was detected with fluorescein isothiocyanate conjugated 1:400 diluted goat antihuman IgG (Kallestad, Chaska, Minnesota, USA). Finally, the slides were washed again in PBS and mounted in glycerin PBS for immunofluorescence microscopy.

Samples were scored as positive if most neutrophils showed positive fluorescence. Staining patterns were described as 'cytoplasmic' when granular staining of the cytoplasm with accentuation between the nuclear lobes was present, as 'perinuclear' when a (peri)nuclear pattern was seen, and as 'atypical cytoplasmic' when cytoplasmic staining was non-granular or when the accentuation between nuclear lobes was lacking. ${ }^{27}$ To investigate whether the perinuclear staining pattern seen on ethanol fixed granulocytes was due to redistribution of the antigen(s) involved, cytocentrifuge preparations of neutrophils were also fixed with phosphate buffered paraformaldehyde $(0.5 \%)$ at $\mathrm{pH} 8 \cdot 5 .{ }^{28}$

DETECTION OF AUTOANTIBODIES TO HLE, MYELOPEROXIDASE, AND PROTEINASE 3 by ELISA Detection of autoantibodies to HLE, myeloperoxidase, and proteinase 3 by ELISA was performed as previously described. ${ }^{13}$

\section{Results}

OCCURRENCE AND CLINICAL ASSOCIATION OF HLE ANTIBODIES IN SERUM SAMPLES SUBMITTED ROUTINELY FOR ANCA DETECTION

Five of 913 serum samples with a p-ANCA pattern, one of 189 with an atypical cytoplasmic staining pattern, and none of 50 with a c-ANCA pattern were positive for antibodies to HLE by ELISA (figure). Also, none of 218 serum samples from normal controls with negative immunofluorescence on ethanol fixed granulocytes were positive for anti-HLE. Two of the six samples positive for anti-HLE were simultaneously positive for myeloperoxidase antibodies. Proteinase 3 antibodies were not detected in these six samples. The six serum samples positive for anti-HLE produced a granular cytoplasmic staining pattern on paraformaldehyde fixed granulocytes. These six samples were obtained from five women and one man, mean age 68 (range 55-84) years. Tables 1, 2, and 3 list the clinical, histopathological, and laboratory features of these patients and samples. Four patients had a clinical diagnosis of (limited) Wegener's granulomatosis. Three of them presented with chronic nasal inflammation, persistent sinusitis, constitutional symptoms, fever, and arthralgia and myalgia. In all three patients radiographs of the sinuses showed opacification or fluid levels, whereas chest radiographs disclosed a dense localised infiltrate in two of them. Multiple cultures did not grow bacteria, mycobacteria, or fungi, and antibiotic treatment did not result in clinical improvement. Serum creatinine concentrations were normal in these patients, but urine analysis disclosed a trace of albumin accompanied by haematuria without cellular casts in one of them. According to histopathological criteria a definite diagnosis of Wegener's granulomatosis 


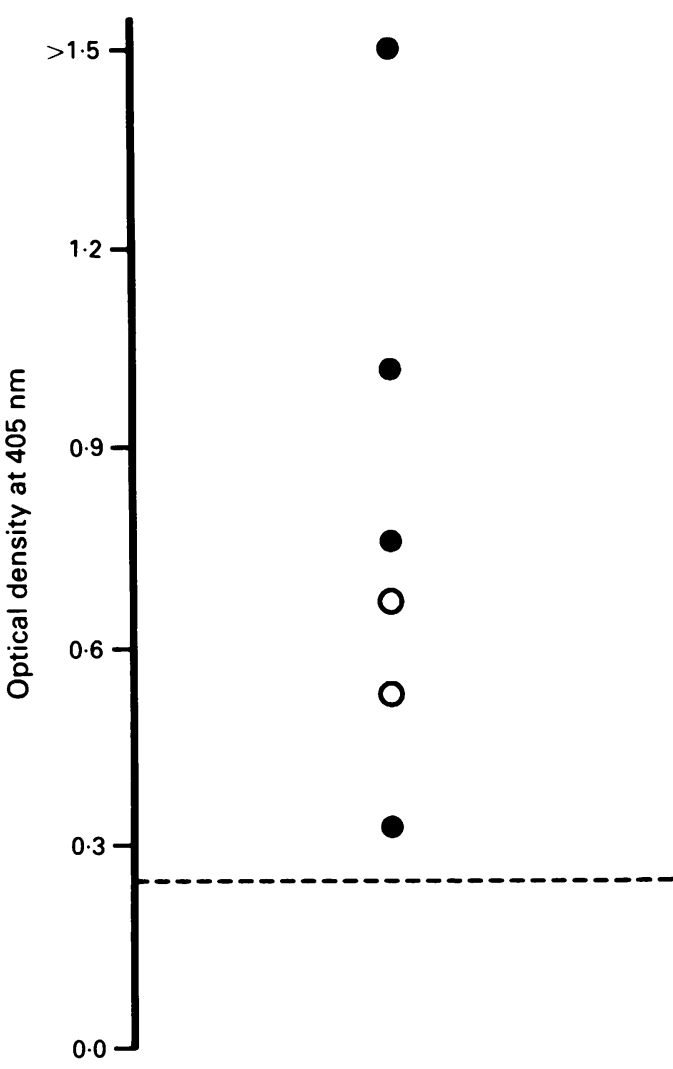

Autoantibodies to human leucocyte elastase (HLE) as detected by ELISA in six of 1152 serum samples that were routinely submitted for the detection of antineutrophil cytoplasmic antibodies and produced a (peri)nuclear or cytoplasmic staining pattern by indirect immunofluorescence on ethanol fixed granulocytes. Open circles represent serum samples that are positive both for myeloperoxidase antibodies and for anti-HLE, and solid circles represent serum samples that are positive for anti-HLE only. Dashed line denotes the upper limit of control samples (mean $+2 S D)$.

could not be made in these patients, although extravascular granulomatous inflammation was found in a nasal biopsy specimen in one patient (patient 1) and vasculitis of the skin in another (patient 3) (table 2). Open lung biopsies and renal biopsies were, however, not performed. Treatment with high dose prednisolone (accompanied by oral cyclophosphamide in one patient (patient 1)) resulted in prompt recovery in all three patients.

Patient 4 presented with cough and severe dyspnoea. A chest radiograph disclosed multiple interstitial infiltrates, and a transbronchial biopsy showed extravascular granulomatous inflammation without vasculitis (table 2). No upper respiratory tract or renal manifestations were present. Treatment with high dose corticosteroids resulted in partial remission. Because of progressive dyspnoea while the dose of steroids was generally reduced (four months after diagnosis) an open lung biopsy was performed that disclosed nodular interstitial fibrosis with cicatricial vascular changes without signs of active vasculitis. Bronchoalveolar lavage performed at that time, however, showed a pronounced increase in neutrophils and eosinophils compatible with active Wegener's granulomatosis. ${ }^{29}$ Dosage of steroids was increased and treatment with oral cyclophosphamide started, resulting in a remarkable clinical improvement.

Patient 5 had Cogan's syndrome. She had a three year history of audiovestibulatory abnormalities consisting of vertigo, bilateral tinnitus, nausea, vomiting, nystagmus, and bilateral hearing loss. Interstitial keratitis in combination with uveitis was also present, but other manifestations of systemic vasculitis were not seen.

Patient 6 had systemic vasculitis and was classified as having polyangiitis overlap syndrome. This patient has already been described. ${ }^{17}$

\section{OCCURRENCE OF HLE ANTIBODIES IN GROUPS OF} PATIENTS WITH SELECTED DISEASES

To further test for the prevalence of anti-HLE and its relation to anti-myeloperoxidase and anti-proteinase 3 we analysed serum samples from consecutive patients with different forms of vasculitis $(n=61)$, necrotising crescentic glomerulonephritis $(n=45)$, and chronic midline destructive disease $(n=14)$ who were seen at the department of internal medicine, University Hospital, Groningen, The Netherlands, during a period of more than six years (table 4). Antibodies to HLE were only found in one patient with chronic midline destructive disease (patient 1 ) and in one patient with polyangiitis overlap syndrome (patient 6). To assess the specificity of anti-HLE for systemic vasculitis we tested serum samples from patients with systemic lupus erythematosus $(n=38)$, rheumatoid arthritis $(n=38)$, granulomatous disorders

Table 1 Clinical features of six patients with human leucocyte elastase antibodies

\begin{tabular}{|c|c|c|c|}
\hline $\begin{array}{l}\text { Patient } \\
\text { No }\end{array}$ & $\begin{array}{l}\text { Upper respiratory } \\
\text { tract findings }\end{array}$ & $\begin{array}{l}\text { Pulmonary disease } \\
\text { findings }\end{array}$ & Other manifestations \\
\hline 1 & $\begin{array}{l}\text { Rhinitis, sinusitis, } \\
\text { destructive midline } \\
\text { disease }\end{array}$ & $\begin{array}{l}\text { Haemoptysis } \\
\text { Chest } x \text { ray film: localised } \\
\text { consolidation }\end{array}$ & $\begin{array}{l}\text { Fever, arthralgia, } \\
\text { pyoderma gangrenosum }\end{array}$ \\
\hline 2 & Rhinitis, sinusitis & $\begin{array}{l}\text { Cough, dyspnoea } \\
\text { Chest } x \text { ray film: localised } \\
\text { consolidation }\end{array}$ & Fever, myalgia \\
\hline 3 & Rhinitis, sinusitis & $\begin{array}{l}\text { Cough, dyspnoea } \\
\text { Chest } x \text { ray film: no abnormalities }\end{array}$ & $\begin{array}{l}\text { Fever, arthralgia, } \\
\text { purpura, proteinuria, } \\
\text { haematuria }\end{array}$ \\
\hline 4 & - & $\begin{array}{l}\text { Cough, dyspnoea } \\
\text { Chest } x \text { ray film: diffuse } \\
\text { bilateral interstitial } \\
\text { infiltrates }\end{array}$ & Fever \\
\hline 5 & - & - & $\begin{array}{l}\text { Interstitial keratitis, } \\
\text { audiovestibular } \\
\text { symptoms, alopecia }\end{array}$ \\
\hline 6 & & - & $\begin{array}{l}\text { Fever, myalgia, } \\
\text { arthralgia, polyneuropathy, } \\
\text { skin nodules }\end{array}$ \\
\hline
\end{tabular}


Table 2 Histopathological findings for six patients with antibodies to human leucocyte elastase (HLE)

\begin{tabular}{|c|c|}
\hline Patient No & Histological findings \\
\hline 1 & $\begin{array}{l}\text { Nasal biopsy: acute and chronic inflammation with necrosis, mucosal ulceration, eosinophilic granulocytes, } \\
\text { histiocytes, and giant cells }\end{array}$ \\
\hline 2 & Nasal biopsy: acute and chronic inflammation with mucosal ulceration \\
\hline 3 & Nasal biopsy: acute and chronic inflammation with mucosal ulceration. Skin biopsy: leucocytoclastic vasculitis \\
\hline 4 & $\begin{array}{l}\text { Transbronchial biopsy: chronic inflammation with a mixed infiltrate of neutrophils, eosinophilic granulocytes, and } \\
\text { scattered giant cells }\end{array}$ \\
\hline & $\begin{array}{l}\text { Open lung biopsy*: nodular interstitial fibrosis with cicatricial vascular changes. } \\
\text { Muscle biopsy }{ }^{*} \text { mild non-specific perivascular inflammation }\end{array}$ \\
\hline 5 & No biopsy \\
\hline 6 & Subcutaneous nodule: granulomatous arteritis \\
\hline
\end{tabular}

Table 3 Laboratory results for six patients with antibodies to human leucocyte elastase at the time of active disease and before the start of treatment

\begin{tabular}{|c|c|c|c|c|c|c|c|c|}
\hline \multirow[t]{2}{*}{$\begin{array}{l}\text { Patient } \\
\text { No }\end{array}$} & \multirow[t]{2}{*}{$\begin{array}{l}E S R \\
(m m / h)\end{array}$} & \multirow[t]{2}{*}{$\begin{array}{l}H b \\
(\mathrm{~g} / \mathrm{l})\end{array}$} & \multirow[t]{2}{*}{$\begin{array}{l}W B C \\
\left(10^{y} / l\right)\end{array}$} & \multirow[t]{2}{*}{$\begin{array}{l}\text { Hyper- } \\
\text { eosinophilia } \\
\left(>0 \cdot 5 \times 10^{9} / l\right)\end{array}$} & \multirow[t]{2}{*}{$\begin{array}{l}\text { Thrombocytes } \\
\left(10^{\prime \prime} / l\right)\end{array}$} & \multirow[t]{2}{*}{$\begin{array}{l}(\ell, \text { anti- } \\
\text { trypsin }(g / l)^{*}\end{array}$} & \multicolumn{2}{|c|}{$\begin{array}{l}\text { Antineutrophil } \\
\text { cytoplasmic } \\
\text { antibodies }\end{array}$} \\
\hline & & & & & & & $I F$ & ELISA \\
\hline $\begin{array}{l}1 \\
2 \\
3 \\
4\end{array}$ & $\begin{array}{r}32 \\
118 \\
85 \\
76\end{array}$ & $\begin{array}{l}113 \\
125 \\
106 \\
140\end{array}$ & $\begin{array}{r}10 \\
11 \\
7 \\
18\end{array}$ & $\begin{array}{l}- \\
- \\
- \\
+\end{array}$ & $\begin{array}{l}633 \\
471 \\
238 \\
378\end{array}$ & $\begin{array}{l}1 \cdot 9 \\
6 \cdot 0 \\
2 \cdot 9 \\
3 \cdot 3\end{array}$ & $\begin{array}{l}\mathbf{p} \\
\mathbf{p} \\
\mathbf{p} \\
\mathbf{c}\end{array}$ & $\begin{array}{l}\text { Anti-HLE } \\
\text { Anti-HLE } \\
\text { Anti-HLE } \\
\text { Anti-HLE and } \\
\text { anti-MPO }\end{array}$ \\
\hline 5 & 81 & 128 & 13 & + & 382 & $2 \cdot 4$ & p & $\begin{array}{l}\text { Anti-HLE and } \\
\text { anti-MPO }\end{array}$ \\
\hline 6 & 75 & 126 & 22 & - & 836 & $3 \cdot 5$ & p & Anti-HLE \\
\hline
\end{tabular}

${ }^{*}$ Reference range for $\alpha_{1}$ antitrypsin $1 \cdot 5-3 \cdot 0 \mathrm{~g} / \mathrm{l}$

$\mathrm{ESR}=$ Erythrocyte sedimentation rate; $\mathrm{Hb}=$ haemoglobin; $\mathrm{WBC}=$ white blood cell count; $\mathbf{I F}=$ immunofluorescence; ELISA=enzyme linked immunosorbent assay; $p=$ = perinuclear staining pattern; $c=$ atypical cytoplasmic staining pattern; $H L E=$ human leucocyte elastase; $\mathrm{MPO}=$ myeloperoxidase

Table 4 Prevalence of antineutrophil cytoplasmic autoantibodies with specificity for human leucocyte elastase (HLE), proteinase 3 or myeloperoxidase in serum samples from patients with systemic necrotising vasculitis and other closely related diseases, and in serum samples from normal control subjects

\begin{tabular}{|c|c|c|c|c|}
\hline $\begin{array}{l}\text { Disease entity (No of serum samples } \\
\text { tested in parentheses) }\end{array}$ & Antibody to $H L E$ & $\begin{array}{l}\text { Antibody to } \\
\text { proteinase } 3\end{array}$ & $\begin{array}{l}\text { Antibody to } \\
\text { myeloperoxidase }\end{array}$ & None \\
\hline Churg-Strauss syndrome (10) & - & - & 8 & 2 \\
\hline Classic polyarteritis nodosa $(9)$ & - & - & 2 & 7 \\
\hline Polyangiitis overlap syndrome (12) & 1 & 6 & 2 & 3 \\
\hline Temporal arteritis (12) & - & - & - & 12 \\
\hline Takayasu's arteritis (4) & - & - & - & 4 \\
\hline Cutaneous vasculitis (14) & - & - & - & 14 \\
\hline \multicolumn{5}{|l|}{ Necrotising crescentic glomerulonephritis: } \\
\hline Associated with Wegener's granulomatosis (40) & - & 30 & 10 & - \\
\hline Idiopathic (5) & - & 1 & 4 & - \\
\hline Chronic midline destructive disease (14) & 1 & 11 & - & 2 \\
\hline \multicolumn{5}{|l|}{ Systemic lupus erythematosus } \\
\hline With CNS involvement (9) & - & - & - & 9 \\
\hline Without CNS involvement (29) & - & - & - & 29 \\
\hline Rheumatoid arthritis (38) & - & - & - & 38 \\
\hline Sarcoidosis (16) & - & - & 1 & 15 \\
\hline Mycobacterial infections (14) & - & - & 1 & 13 \\
\hline Crohn's disease (24) & - & - & - & 24 \\
\hline Ulcerative colitis (35) & - & 2 & 1 & 32 \\
\hline Autoimmune liver diseases (30) & - & - & $\mathrm{i}$ & 29 \\
\hline Normal controls (218) & - & - & - & 218 \\
\hline
\end{tabular}

CNS $=$ Central nervous system.

$(n=30)$, inflammatory bowel disease $(n=59)$, and autoimmune liver disease $(n=30)$ (table 4). None of these contained anti-HLE.

\section{Discussion}

Autoantibodies specific for HLE are not often found in serum samples from patients with vasculitic disorders. As a reference laboratory we detected HLE antibodies in only six patients during a period of more than six years. For comparison, myeloperoxidase antibodies were detected in 53 patients during a period of 4.5 years, ${ }^{16}$ whereas 20 new cases with proteinase 3 antibodies are detected in our laboratory every year. These data show that in a population of patients with suspected vasculitis and glomerulonephritis anti-proteinase 3 antibodies occur 20 times more often than anti-HLE and antimyeloperoxidase 12 times more often. Recently, the fact that the occurrence of anti-HLE is rare has also been reported by others. ${ }^{15} 2230$

Four of six patients with HLE antibodies had a clinical diagnosis of (limited) Wegener's granulomatosis, one patient had Cogan's syndrome, and one patient had polyangiitis overlap syndrome. None of the four patients with a clinical diagnosis of Wegener's granulomatosis had a definite histological proof of that diagnosis. Histological findings of biopsy specimens of the respiratory tract, however, showed an inflammatory reaction with necrosis and granulomatous changes in two of four patients. Vasculitis was not found in these specimens. Because vasculitis can easily be missed in small biopsy specimens, larger biopsies of the nose and sinus or open lung biopsies might have been diagnostic. Vasculitis may also be missed in these larger biopsy specimens, ${ }^{31}$ however, and it has been emphasised that a diagnosis of Wegener's 
granulomatosis sometimes has to be made in the absence of vasculitis. ${ }^{32-34}$ Also, one patient had leucocytoclastic vasculitis of the skin. Although granulomatous inflammation was not detected in respiratory tract biopsy specimens, this patient fulfilled the American College of Rheumatology 1990 criteria for the classification of Wegener's granulomatosis. ${ }^{35}$

Antibodies to HLE produced a perinuclear staining pattern on ethanol fixed normal human granulocytes in five of six patients. This staining pattern proved an artefact of fixation as a granular staining pattern of the cytoplasm was seen when neutrophils were treated with cross linking fixatives such as paraformaldehyde; this has also been shown for anti-myeloperoxidase. ${ }^{12}$

In the present study we detected HLE antibodies and myeloperoxidase antibodies simultaneously in two patients. The combined presence of these has already been described, and it has been suggested that this combination of antibodies might be diagnostic of hydralazine induced glomerulonephritis. ${ }^{15}$ Their simultaneous occurrence has recently been reported, however, in some patients with connective tissue diseases. ${ }^{36}$ As we did not have the opportunity to study cases of hydralazine induced glomerulonephritis we were not able to verify the hypothesis. Our two patients with both anti-HLE and anti-myeloperoxidase, however, did not use hydralazine, nor did they have clinical evidence of glomerulonephritis. Antibodies to HLE have also occasionally been found in patients with idiopathic systemic lupus erythematosus. Nässberger et al ${ }^{15}$ found antiHLE in four of 96 patients with systemic lupus erythematosus, and three of them had involvement of the central nervous system. In the present study we could not confirm this report as we did not find HLE antibodies in patients with active systemic lupus erythematosus (with or without central nervous system disease). During the third international workshop on ANCAs (November 1990, Washington DC) the occurrence of anti-HLE in patients with systemic lupus erythematosus was debated, as at least some positive results may, in fact, be due to interaction of HLE with DNA. ${ }^{30}$

The rare occurrence of HLE antibodies in patients with Wegener's granulomatosis, which is strongly associated with anti-proteinase $3,{ }^{3-5}$ has not been described before. Both proteinase 3 and HLE are serine proteinases with elastinolytic activity and both enzymes are involved in tissue destruction. This may suggest a common background for the autoimmune responses.

In conclusion, autoantibodies to HLE are rarely found in serum samples from patients with vasculitis. Testing for HLE antibodies seems to be useful only in patients with active Wegener's granulomatosis or systemic vasculitis who lack antibodies to proteinase 3 and myeloperoxidase.

This study was supported by grants C84.514 and C85.552 from he Dutch Kidney Foundation.

We thank Drs P van Boven (Tilburg) and A van der Wiel (Amersfoort) and other colleagues for sending serum samples to our laboratory and for providing clinical data. We thank Dr J Marrink for $\alpha 1$-antitrypsin tests, Dr H A Cats for samples from patients with temporal arteritis, Dr D S Postma for samples from sarcoidosis patients, Dr J Steensma for samples from patients with mycobacterial infections, Dr G F Nelis for samples from patients with inflammatory bowel diseases, Dr E B Haagsma for samples from patients with autoimmune liver diseases, and we are grateful to Kiki Bugter for preparation of the manuscript.

1 Kallenberg C G M, Cohen Tervaert J W, van der Woude F J Goldschmeding R, von dem Borne A E G Kr, Weening J J Autoimmunity to lysosomal enzymes: new clues to vasculitis and glomerulonephritis? Immunol Today 1991; 12: 61-4.

2 Ramirez G, Khamasta M A, Hughes G R V. The ANCA test its clinical relevance. Ann Rheum Dis 1990; 49: 741-2.

3 Van der Woude F J, Rasmussen N, Lobatto S, et al. Autoantibodies to neutrophils and monocytes: a new too for diagnosis and a marker of disease activity in Wegener's granulomatosis. Lancet 1985; ii: 425-9.

4 Nölle B, Specks V, Lüdemann J, Rohrbach M S, De Remee D A, Gross W L. Anticytoplasmic autoantibodies: their immunodiagnostic value in Wegener's Granulomatosis. Ann Intern Med 1989; 111: 28-40

5 Cohen Tervaert J W, van der Woude F J, Fauci A S, et al. Association between active Wegener's Granulomatosis and anticytoplasmic antibodies. Arch Intern Med 1989; 149: 2461-5.

6 Wiik A. Delineation of a standard procedure for indirect immunofluorescence detection of ANCA. APMIS 1989; 97 (suppl 6): 12-3.

7 Goldschmeding R, van der Schoot C E, ten Bokkel Huinink $\mathrm{D}$, et al. Wegener's Granulomatosis autoantibodies identif a novel diisopropylfluorophosphate-binding protein in the a novel diisopropylfluorophosphate-binding protein in the
lysosomes of normal human neutrophils. $\mathcal{F}$ Clin Invest lysosomes of normal

8 Niles J L, McCluskey R T, Ahmad M F, Arnaout M A Wegener's Granulomatosis autoantigen is a novel serine proteinase. Blood 1989; 74: 1888-93.

9 Lüdemann J, Utecht B, Gross W L. Anti-neutrophil cytoplasm antibodies in Wegener's Granulomatosis recognize an elastinolytic enzyme. F Exp Med 1990; 171: 357-62.

10 Jennette J C, Hoidal J H, Falk R J. Specificity of antineutrophil cytoplasmic autoantibodies for proteinase 3 . Blood 1990; 78: 2263-4.

11 Campanelli D, Melchior M, Fu Y, et al. Cloning of cDNA for proteinase 3: a serine protease, antibiotic, and autoantigen proteinase 3: a serine protease, antibiotic, and autoantigen

12 Falk R J, Jennette J C. Anti-neutrophil cytoplasmic autoantibodies with specificity for myeloperoxidase in patients with systemic vasculitis and idiopathic necrotizing and crescentic glomerulonephritis. N Engl f Med 1988; 318 1651-7.

13 Cohen Tervaert J W, Goldschmeding R, Elema J D, et al. Autoantibodies against myeloid lysosomal enzymes in crescentic glomerulonephritis. Kidney Int 1990;37:799-806.

14 Lee S S, Adu D, Thompson A. Anti-myeloperoxidase antibodies in systemic vasculitis. Clin Exp Immunol 1990 79: 41-6.

15 Nässberger L, Sjöholm A G, Jonsson H, Sturfelt G, Åkessen A. Autoantibodies against neutrophil cytoplasm components in systemic lupus erythematosus and in hydralazine-induced in systemic lupus erythematosus and in hydra

16 Cohen Tervaert J W, Goldschmeding R, Elema J D, et al. Association of autoantibodies to myeloperoxidase with Association of autoantibodies to myeloperoxidase with
different forms of vasculitis. Arthritis Rheum 1990; 33: different

17 Cohen Tervaert J W, Limburg P C, Elema J D, et al. The detection of autoantibodies against myeloid lysosomal enzymes: a useful adjunct to classification of patients with biopsy-proven necrotizing arteritis. Am J Med 1991; 91 $59-66$.

18 Duerr R H, Targan S R, Landers C J, et al. Neutrophil cytoplasmic antibodies: a link between primary sclerosing cholangitis and ulcerative colitis. Gastroenterology 1991; 100: 1385-91.

19 Cohen Tervaert J W, Mulder A H L, Horst G, Haagsma E B Kleibeuker J H, Kallenberg C G M. Antineutrophil cytoplasmic antibodies in primary sclerosing cholangitis, cytoplasmic antibodies in primary sclerosing cholangitis,
ulcerative colitis, and autoimmune liver diseases. Gastroulcerative colitis, and auto
enterology 1992; 102: 1090 .

20 Thomson R A, Lee S S. Antineutrophil cytoplasmic antibodies. Lancet 1989; i: 670-1.

21 Goldschmeding R, Cohen Tervaert J W, van der Schoot C E van der Veen $C$, Kallenberg $C \mathrm{G} M$, von dem Borne A E G Kr. ANCA, anti-myeloperoxydase and anti-elastase: three members of a novel class of autoantibodies against myeloid lysosomal enzymes. APMIS 1989; 97 (suppl 4): 48-9.

22 Nässberger L, Jonsson H, Sjöholm A G, Sturfelt G. Circulating anti-elastase in systemic lupus erythematosus (letter). Lancet 1989; i: 509 .

$23 \mathrm{Lie} \mathrm{J} \mathrm{T.} \mathrm{Systemic} \mathrm{and} \mathrm{isolated} \mathrm{vasculitis.} \mathrm{A} \mathrm{rational} \mathrm{approach}$ to classification and pathologic diagnosis. Pathol Annu 1989; 24: 25-114.

24 Tsokos M, Fauci A S, Costa J. Idiopathic midline destructive disease (IMDD). A subgroup of patients with the 'midline granuloma' syndrome. Am f Clin Pathol 1982; 77: 162-8.

25 ter Borg E J, Horst G, Hummel E J, Limburg P C, Kallenberg C G M. Predictive value of rises in anti-double stranded DNA antibody levels for disease exacerbations in systemic lupus erythematosus: a long term prospective
study. Arthritis Rheum 1990; 33: 634-43.

26 van der Giessen $M$, Huitema $M$ G, Cohen Tervaert J W Kallenberg C G M. A technical note on the routinely performed ANCA detection. APMIS 1989; 97 (suppl 6):
37 . 
27 Rasmussen N, Wiik A. Indirect immunofluorescence examination for IgG-ANCA in sera submitted for the Is international workshop on ANCA, 1988. APMIS 1989; 97 (suppl 6): 16-20.

28 Mulder A H L, Horst G, de Weerd H, van Leeuwen M A Limburg P C, Kallenberg C G M. Granulocyte-specific compound of the granulocyte. Clin Rheumatol 1990; 9: comp
578 .

29 Hoffman G S, Sechler J M G, Gallin J I, et al. Bronchoalveolar lavage analysis in Wegener's Granulomatosis. A method to study disease pathogenesis. Am Rev Respir Dis 1991; 143: 401-7.

30 Lesavre Ph. Antineutrophil cytoplasmic autoantibodies antigen specificity. Am F Kidney Dis 1991; 18: 159-63.

31 Mark E J, Matsubara O, Tan-Liu N S, Fienberg R. The pulmonary biopsy in the early diagnosis of Wegener's (pathergic) granulomatosis: a study based on 35 open lung biopsies. Hum Pathol 1988; 19: 1065-71.

32 Fienberg $\mathbf{R}$. The protracted superficial phenomenon in pathergic (Wegener's) granulomatosis. Hum Pathol 1981; 12: 458-67.

33 Shah I A, Holstege A, Riede V N. Bioptic diagnosis of Wegener's granulomatosis in the absence of vasculitis and granulomas. Pathol Res Pract 1984; 178: 407-12.

34 Boudes P. Purely granulomatous Wegener's granulomatosis: a new concept for an old disease. Semin Arthritis Rheum 1990; 19: 365-70.

35 Leavitt R Y, Fauci A S, Bloch D A, et al. The American College of Rheumatology 1990 criteria for the classification of Wegener's granulomatosis. Arthritis Rheum 1990; 33: $1101-7$

36 Gallichio M C, Savige J A. Detection of anti-myeloperoxidase and anti-elastase antibodies in vasculitides and infections. Clin Exp Immunol 1991; 84: 232-7. 